\title{
Good Questions 4: Is Prohibiting Famine Worthwhile?
}

I am a huge admirer of Alex de Waal's decades of work on famine. He recently provided World Nutrition with an important article on the idea of ending famine through prohibition of it in the law (de Waal 2018a; also see de Waal 2018b; Green 2018). While the prohibition idea has intrinsic appeal, I doubt its feasibility.

\section{PROHIBITING VIOLATIONS NOT LIKELY TO BE EFFECTIVE}

My perspective has been darkened partly because of the work of a colleague of mine, the late Rudolph Rummel. He devoted much of his professional life to documenting the large-scale killing by governments of their own people outside of warfare. Many readers view his findings with disbelief or simply avoid thinking about them. His work covered many famines, but they account for only a fraction of the harm that has been inflicted by governments on their own people. His website is still accessible (Rummel 2002) and Wikipedia has a biography on him and his work.

All of those outrages should have been prohibited. It can be extremely difficult to get agreement on the idea. The Treaty on the Prohibition of Nuclear Weapons has been ratified by only seven countries, but it requires 50 ratifications before it goes into force. Some outrages have been prohibited on paper but are very difficult to implement. The Convention on the Prevention and Punishment of the Crime of Genocide is in force, technically, but it is clear that not all genocide has been prevented. Remarkably, it is the only major human rights treaty for which there is no permanent United Nations committee to oversee its implementation.

What would prohibition of imposed starvation or other atrocities mean in terms of action? What would be done to prevent future wrongful actions? Current ones? Who would do what? With what resources?

Would prohibition be based on the premise that that causing famine is a criminal act? Would prosecution rely on demonstrating criminal intent? Would simply allowing famine to occur be viewed as a criminal act? Who is to decide when a famine has occurred? How? How would blame be allocated?

The Food and Agriculture Organization of the United Nations, the World Health Organization, the United Nations Children's Fund, the World Food Programme, international nongovernmental organizations and many national governments and private foundations already address food insecurity issues in various ways. How could they or other agencies pursue the prohibition approach?

\section{FOCUS ON ASSISTANCE}

Instead of trying to prosecute violations, it might be more useful to focus on what the global community should do to help people in extreme distress. 
While causing a famine to occur surely is wrong, so is the refusal to help the victims, especially when that can be done easily. De Waal discusses a famine in 1816 caused by crop failure. At that time, perhaps no one could reach the victims in a timely way. Today, no emergency on earth is beyond reach. Armed resistance to incoming humanitarian aid might explain some cases of failures to assist, but very few.

Systematic methods for assessing needs have been developed by the United Nations Office for the Coordination of Humanitarian Affairs (UNOCHA 2018a). The methods for providing assistance in cases of extreme need are clear. The missing piece is adequate motivation to help those in need. The global community, taken as a whole, does not care enough about the hunger problem (Kent, ed. 2008; 2016). The shortfalls in global contributions for humanitarian assistance are well documented (UNOCHA 2018b).

\section{RIGHTS TO ASSISTANCE AND OBLIGATIONS TO ASSIST}

Instead of prosecuting violators, it might be more useful to focus on the ways in which the global community, taken as a whole, could systematically assist people in extreme distress. The global human rights system could articulate clear rights to humanitarian assistance under some circumstances, along with the corresponding obligations of members of the global community to provide that assistance.

The global community could commit to providing humanitarian assistance in cases of extreme food insecurity and other types of great distress. Although assistance might sometimes be refused by uncooperative local leaders, such assistance should at least be offered. It is understandable that the international community would not assist in violent conflict situations or when governments refused to allow the food to go to those who need it, but often the appeals for help go unheeded even where they would be welcomed. In extreme cases, there should be an obligation to at least offer international humanitarian assistance (Kent 2000; 2001; 2013; Kent, ed. 2008, 203-227.).

People in great distress should be offered help, no matter what caused it. The duty to rescue should take priority over the urge to identify and punish whoever might have caused the problem. There is a need for concern about the safety of rescuers, but if they can get assured "safe passage", there is no good reason, morally, to hold back.

The Global Platform for the Integrated Food Security Phase Classification system has well established methods for guiding food security decisions (IPC 2018). Currently its analysis shows that the most extreme situation, which they label acute food insecurity, is affecting South Sudan, Afghanistan, Yemen, and the Central African Republic. Food security in those places has gotten extremely bad because of sustained violent conflict. The global community, especially the richer and more powerful countries, should make a specific proposal to the parties controlling the situation to enable them to provide suitable assistance. They could say that if you guarantee us safe passage, we will deliver food and other goods. In some cases, they might offer to evacuate non-combatants who are willing to leave. They could be required to pass an agreed screening process before being taken to host countries that have indicated their willingness to take them. 
In some situations, it might be impossible to negotiate adequately safe passage. This would not relieve the international community of the obligation to provide assistance in extreme distress situations in which the assistance would be safe and welcomed. This approach would not be easy to implement. However, agencies like the International Red Cross and Doctors Without Borders have many skills and tools that could be applied. The approach is worth exploring.

The system of rights-based global humanitarian assistance could be started with a focus on cases of extreme distress in which there is no resistance to offers of assistance. Over time, it could cover more moderate forms of distress. The ways in which emergency services are organized in local communities could be adapted for global emergency service operations.

\section{REFERENCES}

De Waal, Alex. 2018a. “Social Nutrition and Prohibiting Famine.” World Nutrition. 9(1): 31-35. https://worldnutritionjournal.org/index.php/wn/article/view/172/127

---. 2018b. Mass Starvation: The History and Future of Famine. Cambridge, United Kingdom. Polity Press.

Green, Andrew. 2018. “To End Famines, Prosecute Leaders Who Use Hunger as a Weapon: Expert.” Malnutrition Deeply. June 6. https://www.newsdeeply.com/malnutrition/community/2018/06/06/to-end-faminesprosecute-leaders-who-use-hunger-as-a-weapon-expert

IPC. 2018. Evidence and Standards for Better Food Security Decisions. Integrated Food Security Phase Classification (IPC). http://www.ipcinfo.org/

Kent, George. 2000. “U.S. Targeting of International Humanitarian Assistance,” in David P. Forsythe, ed., The United States and Human Rights: Looking Inward and Outward (Lincoln: University of Nebraska Press. http://www2.hawaii.edu/ kent/USTargetingIHA.pdf

---. 2001, “The Human Right to Disaster Mitigation and Relief” Environmental Hazards. 3(3): 137-138. http://www2.hawaii.edu/ kent/disaster.pdf

---. 2010. "Disasters and 'Responsibility to Protect: Should Nations Force Aid on Others? Rights and Obligations.” Natural Hazards Observer, January. 1, 18-22. http://www2.hawaii.edu/ kent/ShouldNationsForce.pdf Republished in Disaster Prevention and Management, 2014. 23(3). http://www2.hawaii.edu/ kent/DPMRightsandObligationsinIHA.pdf

---. 2013. "Rights and Obligations in International Humanitarian Assistance.” Encyclopedia of Natural Hazards. Heidelberg, Germany: Springer, 2013. 851-855. 
http://www2.hawaii.edu/ kent/RightsObligationsinIHA.pdf Republished in Disaster Prevention and Management, 2014, 23(3).

---. 2016. Caring About Hunger. Sparsnäs, Sweden: Irene Publishing.

Kent, George, ed. 2008. Global Obligations for the Right to Food. Lanham, Maryland: Rowman and Littlefield.

Rummel, Rudolph. 2014. Website. https://www.hawaii.edu/powerkills/PERSONAL.HTM

UNOCHA 2018a. Needs Assessment. United Nations Office for the Coordination of Humanitarian Affairs. Geneva. https://www.unocha.org/themes/needs-assessment

---. 2018b. Global Humanitarian Overview 2018. United Nations Office for the Coordination of Humanitarian Assistance.

Geneva.http://interactive.unocha.org/publication/globalhumanitarianoverview/ 